\title{
How Proficiency-Pairing Affects Students' Peer-Mediated Revisions of EFL Writing: Three Case Studies
}

\author{
Weiqiang Wang ${ }^{1}$ \\ ${ }^{1}$ School of English for International Business, Guangdong University of Foreign Studies, Guangzhou, China \\ Correspondence: Weiqiang Wang, North Baiyun Avenue, Guangzhou 510420, China. Tel: 86-138-2640-1248. \\ E-mail: wilburwong@gdufs.edu.cn
}

Received: November 25, 2014 Accepted: March 7, 2015 Online Published: April 23, 2015

doi:10.5539/elt.v8n5p22 URL: http://dx.doi.org/10.5539/elt.v8n5p22

\begin{abstract}
The present study reports on a teacher's classroom-based research into the influence of proficiency-pairing on students' peer-mediated draft revisions. Three students of an EFL writing course at a Chinese university, who formed into peer dyads with their classmates voluntarily, participated in the study. Throughout the EFL writing course, they wrote five expository essays at different time points, had their EFL writing assessed by their peers, and revised their drafts based on the peer feedback received. Results showed that 1) When two students of high proficiency formed a dyad, a high-proficiency student's peer-mediated revisions were mainly about the global aspects of EFL writing; 2) When two students of intermediate proficiency formed a dyad, an intermediate-proficiency student's peer-mediated revisions were almost evenly distributed among the global and local aspects of EFL writing; 3) When a student of intermediate proficiency formed a pair with a student of low proficiency, the intermediate-proficiency student's peer-mediated revisions mainly centered on the local aspects of EFL writing. Implications are drawn for using multiple-peer groupings and fine-tuning teacher's feedback on the writing of students of differing proficiency in the Chinese EFL writing context.
\end{abstract}

Keywords: classroom-based research, draft revisions, peer dyads, proficiency-pairing

\section{Introduction}

Peer feedback has been a heated topic in second language writing research for the past two decades. Its role as an important supplement to teacher feedback has been well demonstrated in L2 writing literature. Most of the previous empirical studies on peer feedback have investigated its effectiveness for improving students' L2 writing (e.g., Connor \& Asenavage, 1994; Paulus, 1999; Shih-hsien, 2011; Villamil \& Guerrero, 1998a; Yang, Badger, \& Yu, 2006) and the dynamics of pair interaction in peer feedback sessions (e.g., Guerrero \& Villamil, 1994; Mendonca \& Johnson, 1994; Storch, 2002a; Villamil \& de Guerrero, 1996; Zhu, 2001). However, most of the previous research on students' interaction in peer feedback sessions was conducted in ESL writing contexts and mainly investigated how students interacted with each other, such as their stances, turn-taking behaviors, language functions, and written comments, etc. There is, however, much less empirical research studying the effect of proficiency-pairing on students' peer-mediated draft revisions in the EFL writing context. Although Topping (1998) proposed that students should be of equal status when paired into peer assessment dyads, this is a rather idealistic situation since "there are evidently individual differences that affect perceived status and may impact peer feedback perceptions and subsequent performance" (Strijbos, Narciss, \& Dnebier, 2010, p. 292).

The present study reports a classroom-based research into the effects of proficiency-pairing on Chinese students' use of peer feedback in their revisions of EFL writing, investigating in particular the influence of three types of proficiency-pairing on students' peer-mediated draft revisions: high proficiency-high proficiency $(\mathrm{H}-\mathrm{H})$, intermediate proficiency-intermediate proficiency (I-I), and intermediate proficiency-low proficiency (I-L).

\section{Literature Review}

The implementation of peer feedback sessions in L1 and L2 writing contexts is both theoretically and pedagogically well underpinned. The concept of Zone of Proximal Development (ZPD) (Vygotsky, 1978) and collaborative learning theories (Bruffee, 1973) provide the theoretical basis of viewing students as the valuable sources scaffolding each other's development. Pedagogically, organizing students into peer feedback sessions can offer students an additional source of feedback that is "more immediate, timely, and individualized than 
teacher feedback" (Topping, 2010, p. 62). These benefits become more salient in the face of increasing numbers of students enrolled at higher educational institutions and the resulting enlarged class sizes.

However, a primary concern in peer feedback research in different educational contexts is students' competence for providing feedback on each other's work. This is particularly prominent in L2 writing context, since students as second language learners may be at differing stages of L2 development and thus have differing abilities to provide accurate, informative and useful feedback on L2 writing (e.g., Nelson \& Murphy, 1993; Yang et al., 2006; Zhang, 1995). Students generally regard their teacher as the only authority capable of giving feedback on their L2 writing (e.g., Sengupta, 1998), which may well explain why there has been abundant L2 writing research comparing the efficacy of teacher and peer feedback for students' draft revisions and writing quality improvements (e.g., Chaudron, 1984; Connor \& Asenavage, 1994; Crookes, Davis, \& Caulk, 1994; Jacobs \& Zhang, 1989; Mei \& Yuan, 2010; Paulus, 1999; Shih-hsien, 2011; Tsui \& Ng, 2000; Zhao, 2010) or exploring the effects of training on improving peer feedback quality and usage (e.g., Berg, 1999a, 1999b; Hu, 2005; Liou \& Peng, 2009; Min, 2005, 2006, 2008; Rahimi, 2013; Rollinson, 2005; Stanley, 1992; Zhu, 1995). Moreover, except for a few exceptions (e.g., Berg, 1999a), most of the previous research on peer feedback in L2 writing examined a relatively homogeneous group of students in terms of language proficiency. This approach, however, is relatively broad-brush in that it ignores the possible influence of students'differing proficiency levels on the quality and usage of peer feedback.

It is noteworthy that although students may usually be paired with classmates of similar or different proficiency levels in a L2 writing class, the research investigating the impact of proficiency-pairing in L2 writing remains scant, and most of the research on peer dyads in either L2 writing or language learning in general mainly focused on the process of peer interactions, with little attention paid to the effects of those interactions on students' subsequent draft revisions (e.g., Leeser, 2004; Lockhart \& Ng, 1995; Nelson \& Murphy, 1993; Storch, 1998, 2002a, 2002b, 2005a, 2005b, 2007a, 2007b; Storch \& Aldosari, 2013; Strijbos et al., 2010; Watanabe, 2008; Watanabe \& Swain, 2007). Earlier studies like Lockhart and Ng (1995), Nelson and Murphy (1993), and Storch (2002a) examined the types of student interactions that were likely to result in students' incorporation of a higher percentage of peer response into their draft revisions. Storch (2002a), for instance, identified four patterns of peer interactions and concluded that collaborative and expert/novice patterns of interaction would lead to more peer negotiations and transfer of knowledge than dominant/dominant and dominant/submissive patterns. More recently, Storch and Aldosari (2013) investigated the pair work of 30 Saudi Arabic EFL learners who formed into pairs of either similar or mixed proficiency levels. An examination of the learners' LREs (language related episodes) revealed that $\mathrm{H}-\mathrm{H}$ pairs had more focus on language use than their H-L and L-L equivalents. The research also found that the kind of relationship learners formed in pairs might be a more important consideration than proficiency differences, since collaborative dyadic relationships between students were likely to provide them with more opportunities for language practice than dominant/passive relationships. Those studies, however, have not examined how the formation of student pairs according to their proficiency levels, either similar- or mixed-proficiency dyads, may influence their peer-mediated draft revisions. In another study, Strijbos and Sluijsmans (2010) used the quasi-experimental design to investigate the influence of the competence of peer feedback senders on the peer feedback recipients' draft revisions and found that there were no significant differences between the influences of peer feedback from low and high competence-level senders on peer assessees' writing. Strijbos and Sluijsmans (2010) thus concluded that the differences between peer feedback senders' competence might be ameliorated through the provision of explicit instructions about how to give peer feedback. This study, however, did not explore how students' competence in feedback provision may impact their peers' draft revisions in naturalistic classroom settings.

In naturalistic classroom settings, teachers usually have a group of students of different proficiency and may organize them into similar or mixed-proficiency pairs or groups. As Storch and Aldosari (2013, p. 32) noted, "The L2 proficiency of learners in any one class may vary, and thus decisions have to be made about whether to pair students with similar or different L2 proficiency." There is, however, a lack of research on how pairing students into similar or mixed proficiency dyads may influence their peer-mediated revisions. The present study seeks to fill the research gap by conducting an exploratory study of the role of proficiency-pairing in students' peer-mediated draft revisions.

\section{Research Questions}

The study seeks to address two research questions:

1) How might proficiency-pairing affect individual students' peer-mediated draft revisions?

2) How did individual students perceive their peers' feedback on EFL writing when paired with students of 
similar or different English proficiency?

\section{Methods}

\subsection{Context of the Study}

The study was part of a larger project investigating formative self- and peer assessment in a sophomores' EFL writing course at a university in mainland China. The teacher of the course is also the researcher of the present study, which may offer the research an insider's perspective (Merriam, 1998). The EFL writing course, which covers the teaching of descriptive, narrative, expository and business report writing, features the genre-process pedagogy involving multiple-drafting. At the beginning of the EFL writing course, three 45 -minute sessions were organized to train students to perform self- and peer assessment of their EFL writing using an instructional rubric, which was an adapted version of Jacobs, Zinkgraf, Wormuth, Hartfiel, and Hughey's (1981) ESL Composition Profile.

\subsection{Participants}

Three students, two female and one male, of differing English proficiency, were chosen as the case study informants. Their English proficiency was determined by their performance in the $1^{\text {st }}$ year English courses ranging from Comprehensive English to Listening and their TEM 4 (Test for English Majors, Band 4) scores obtained three weeks after the data collection of the present study. They were all informed of the research purposes of the present study beforehand, signed a consent form and participated in it on a voluntary basis. Table 1 presents the profile of the three case study students. Pseudonyms are used for anonymity purposes.

Table 1. Profile of the case study students and their peers

\begin{tabular}{llllll}
\hline $\begin{array}{l}\text { Case study } \\
\text { students }\end{array}$ & Gender & $\begin{array}{l}\text { Years of English } \\
\text { study }\end{array}$ & Proficiency & $\begin{array}{l}\text { Peer's } \\
\text { name }\end{array}$ & $\begin{array}{l}\text { Peer's English } \\
\text { proficiency }\end{array}$ \\
\hline Catherine & F & 10 & Intermediate & Ivy & Intermediate \\
Susan & F & 12 & High & Lydia & High \\
Kelvin & M & 12 & Intermediate & Nick & Low \\
\hline
\end{tabular}

\subsection{Data Collection}

The data collection of the present study was carried out in the sophomores' EFL writing course, where self- and peer assessment were implemented as integral parts of instruction and lerning. The students were first assigned a topic by the teacher/researcher in the class, brainstormed on the topic for about 30 minutes in groups formed by four to five students, and wrote their first drafts within around 45 minutes. After that, the teacher/researcher photocopied all the drafts and gave the original drafts back to them within the same day, asking them to do self-assessment using the instructional rubric after class. In the next class, the teacher/researcher gave back the photocopied drafts to the students, organizing them into in-class peer response sessions, which generally took around 30 minutes and included both written and oral peer commentary activities. Afterwards, the students were told to revise their first drafts based on the self- and peer feedback generated in the peer response sessions and turned in their second drafts in the next class. The teacher/researcher would then provide feedback on the second drafts and asked them to write the third drafts based on teacher feedback. Their fourth drafts, also the final drafts, would be assigned a score by the teacher/researcher as part of their usual performance in the EFL writing class. The whole cycle of pre-writing, drafting, performing self- and peer assessment, and revision of each essay took around four weeks, and the students wrote altogether one narrative-descriptive and six expository essays in the academic year. Since one of the six expository essays was written as a test-preparation practice, it was not analyzed in the present study. The present study only focused on the students' first and revised drafts of five expository essays (see Appendix A for the expository essay topics).

Moreover, to elicit the students' opinions about peer feedback and intentions of using it, retrospective interviews were conducted with them within one week after they revised the first drafts. Before each interview, the teacher/researcher asked the students to spend around 10 minutes reading the first and revised drafts of each essay, with all the revisions denoted on the second draft. During reading, they were also told to reflect on why they used peer feedback in the way they did. When they were interviewed for the last time, an additional question was added to understand how they evaluatetheir partners' competence for giving peer feedback. As the present study is part of a larger project investigating students' self- and peer assessment practices in the Chinese 
EFL writing context, only those interview questions relevant to the present study are presented (see Appendix B).

\subsection{Data Analysis}

The students' first and revised drafts were compared by using the document comparison function of Office Word 2010 to track the draft revisions. Those revisions were then analyzed by the teacher/researcher and an assistant who has an MA in applied linguistics. The coding scheme used to analyze the revisions was Villamil and Guerrero's (1998) List of troublesources revised. The scheme was chosen because its coverage of five aspects of L2 writing closely corresponds to the five dimensions of EFL writing described in the instructional rubric adapted from Jacobs et al.'s (1981) ESL Composition Profile, ranging from content to mechanics. The teacher/researcher and assistant analyzed all the three students' draft revisions and the inter-rater reliability reached 0.83 , with disagreement resolved through discussion.

The analysis of the interview data used an inductive approach as proposed by many qualitative researchers (e.g., Merriam, 1998; Strauss \& Corbin, 1998), with themes and categories relevant to the second research question generated. Both the teacher/researcher and assistant analyzed the data and came to a consensus over the themes related to it. Given the limited data available for the second research question, no inter-coder reliability of interview data analysis was calculated. To ensure the consistency of data interpretation, the teacher/researcher re-read the interview data three months after the first round of coding and made minor modifications to the coding results. Last but not the least, the results were also communicated to all the three participating students for member check to further enhance the validity of data analysis.

\section{Results}

This section reports the influence of proficiency-pairing on the students' peer-mediated draft revisions. Three patterns of peer-mediated draft revisions were identified: 1) High proficiency level students forming a pair; 2) Intermediate proficiency level students forming a pair; 3) Intermediate and low proficiency students forming a pair. The presentation of each pattern of peer-mediated draft revisions includes two parts: the first part categorizes the students' draft revisions by drawing on the Villamil and Guerrero's (1998) coding scheme and counts the frequency of these revisions; the second part reports the individual students' perceptions of their peers' feedback on EFL writing when paired with peers of similar or different English proficiency.

\subsection{Intermediate Proficiency Students Forming a Pair: Focus on both Global and Local Aspects of EFL Writing}

This subsection describes the pattern of peer-mediated draft revisions when two students of intermediate English proficiency formed a pair. Catherine was a student of intermediate proficiency level in the EFL writing class. Her peer was Ivy, another student of intermediate English proficiency. Table 2 shows that Catherine's peer-mediated revisions were mostly about vocabulary $(15,43 \%)$ and grammar $(8,23 \%)$ ones. Content $(4,11 \%)$ and organization $(7,20 \%)$ revisions also seemed to be the foci of her peer when offering feedback on Catherine's compositions. However, only one peer-mediated mechanics revision (3\%) was made.

Table 2. Catherine's draft revisions made in response to peer feedback

\begin{tabular}{lllllll}
\hline Essay & $\begin{array}{l}\text { Content } \\
\text { revision }\end{array}$ & $\begin{array}{l}\text { Organization } \\
\text { revision }\end{array}$ & $\begin{array}{l}\text { Vocabulary } \\
\text { revision }\end{array}$ & $\begin{array}{l}\text { Grammar } \\
\text { revision }\end{array}$ & $\begin{array}{l}\text { Mechanics } \\
\text { revision }\end{array}$ & Total \\
\hline $1^{\text {st }}$ & $0(0 \%)$ & $2(25 \%)$ & $3(37.5 \%)$ & $3(37.5 \%)$ & $0(0 \%)$ & $8(100 \%)$ \\
$2^{\text {nd }}$ & $2(29 \%)$ & $0(0 \%)$ & $5(71 \%)$ & $0(0 \%)$ & $0(0 \%)$ & $7(100 \%)$ \\
$3^{\text {rd }}$ & $1(11 \%)$ & $2(22 \%)$ & $4(44 \%)$ & $1(11 \%)$ & $1(11 \%)$ & 9 \\
$4^{\text {th }}$ & $0(0 \%)$ & $3(50 \%)$ & $0(0 \%)$ & $3(50 \%)$ & $0(0 \%)$ & $6(100 \%)$ \\
$5^{\text {th }}$ & $1(20 \%)$ & $0(0 \%)$ & $3(60 \%)$ & $1(20 \%)$ & $0(0 \%)$ & $5(100 \%)$ \\
Total & $4(11 \%)$ & $7(20 \%)$ & $15(43 \%)$ & $8(23 \%)$ & $1(3 \%)$ & $35(100 \%)$ \\
\hline
\end{tabular}

Analysis of Catherine's retrospective interview data found that although her peer's feedback touched upon all the five aspects of EFL writing, Catherine mainly relied on her peer's advice on correcting mistakes of language use and selectively followed her peer's suggestions on content revision. For example,

For the first three essays, my peer's comments were mostly useful for improving the local aspects of my EFL writing. My peer pointed out my mistakes in vocabulary, grammar and mechanics use as I had expected. We disagreed in our development of the same topic. For instance, although she also advised me to revise the content 
of the first essay (College Pressures) to keep a balance in the development of the two aspects of college pressures, I did not accept her advice, since I regarded the first aspect of college pressures as more important than the second. At that time, it mainly depended upon self-assessment for content revision. For the fifth essay (The Best Way to Understand the World), however, my peer's suggestions on content revision were really important, because I had digressed from the title by elaborating on the not-so-good ways of understanding the world, without being focused on the best way instead (Catherine, Interview 5).

Catherine also talked about the effectiveness of peer feedback forimproving the organization and the deficiencies of peer feedback for improving the language use of her EFL writing. For instance,

My peer's comments on the organization of my essay are useful. Take the improvement of local coherence for example. My partner would advise me on the addition of connectives to make the sentences more closely connected. She has also pointed out the problems with my tense use, but her comments on vocabulary and grammar use were mainly confined to the diagnosis of mistakes, rather than making the correct language use more accurate and appropriate. In general, I feel that my peer was able to help me develop my essay in a relatively logical manner and avoid making those obvious mistakes of vocabulary and grammar use, but she did not provide sufficient feedback on how to improve the language use, since she did not think that she had the ability to do so (Catherine, Interview 4).

These two examples show that although Catherine acknowledged her peer's help with the identification and correction of those obvious mistakes of language use, she was not satisfied that her peer did not give sufficient advice on making the correct language use "more accurate and appropriate", which might be because her peer was not confident about doing that.

Three findings can be summarized from Catherine's perceptions of her peer's feedback: 1) The peer feedback, which came from a student of intermediate English proficiency, covered almost all the five aspects of Catherine's EFL writing; 2) Catherine would selectively act upon her peer's comments on content revision; 3) Catherine acknowledged her peer's role in helping her correct the mistaken use of vocabulary and grammar, but she doubted her peer's efforts and ability to improve the accuracy and appropriateness of her language use.

\subsection{High Proficiency Students Forming a Pair: Focus on Global Aspects of EFL Writing}

This subsection reports the pattern of peer-mediated draft revisions when two students of high English proficiency formed a pair. Susan was a student of high English proficiency level in the class. She was paired with Lydia, another student of high English proficiency level. Table 3 lists the number of revisions Susan made in response to Lydia's feedback. It shows that among the total number of 23 peer-mediated revisions, content (10, $43 \%)$ and organization $(9,39 \%)$ revisions were two key aspects receiving peer feedback. A closer examination of the content revisions revealed that the 10 content revisions covered both global and local level changes, such as the adjustment of thesis statement(s) and supporting examples, etc. Further analysis of the 9peer-mediated organization revisions found that 5 revisions were aimed at improving the global coherence, such as enriching a concluding paragraph to better summarize the whole essay; 4 were linked to improving the local coherence by adding cohesive devices. Table 3 also shows that relatively few peer-mediated revisions were made to vocabulary $(3,13 \%)$, grammar $(1,4 \%)$, and mechanics $(1,4 \%)$.

Table 3. Susan's draft revisions made in response to peer feedback

\begin{tabular}{lllllll}
\hline Essay & $\begin{array}{l}\text { Content } \\
\text { revisions }\end{array}$ & $\begin{array}{l}\text { Organization } \\
\text { revisions }\end{array}$ & $\begin{array}{l}\text { Vocabulary } \\
\text { revisions }\end{array}$ & $\begin{array}{l}\text { Grammar } \\
\text { revisions }\end{array}$ & $\begin{array}{l}\text { Mechanics } \\
\text { revisions }\end{array}$ & Total \\
\hline $1^{\text {st }}$ & $3(100 \%)$ & $0(0 \%)$ & $0(0 \%)$ & $0(0 \%)$ & $0(0 \%)$ & $3(100 \%)$ \\
$2^{\text {nd }}$ & $3(50 \%)$ & $3(50 \%)$ & $0(0 \%)$ & $0(0 \%)$ & $0(0 \%)$ & $6(100 \%)$ \\
$3^{\text {rd }}$ & $4(44 \%)$ & $3(33 \%)$ & $2(23 \%)$ & $0(0 \%)$ & $0(0 \%)$ & $9(100 \%)$ \\
$4^{\text {th }}$ & $0(0 \%)$ & $2(100 \%)$ & $1(0 \%)$ & $0(0 \%)$ & $0(0 \%)$ & $3(100 \%)$ \\
$5^{\text {th }}$ & $0(0 \%)$ & $1(50 \%)$ & $0(0 \%)$ & $0(0 \%)$ & $1(50 \%)$ & $2(100 \%)$ \\
Total & $10(41 \%)$ & $9(38 \%)$ & $3(13 \%)$ & $1(4 \%)$ & $1(4 \%)$ & $24(100 \%)$ \\
\hline
\end{tabular}

Analysis of Susan's retrospective interview data found that Lydia's feedback was mostly related to content and organization revisions, such as fitting the content with the assigned essay topics or making the topic sentences of 
body paragraphs more closely linked to the thesis statement of an essay. For example,

My peer's comments were mainly about the content and organization of my EFL writing. For example, she would focus on whether the topic sentences in my body paragraphs well echoed the thesis statement, and whether the topic sentences were concise and generalizable enough, etc. My peer's feedback made me further realize the importance of structuring the content more properly and appropriately. She would also tell me that there was a lack of clarity with my topic sentences and that the development of body paragraphs should more closely follow their topic sentences (Susan, Interview 5).

More specifically, Susan talked about how Lydia helped her make large-scale content and local-level organization revisions. For instance,

Take this essay (the $3^{\text {rd }}$ essay titled The Post-90 Generation and Others) as an example. My first draft had a very general thesis statement. I originally wanted to develop this title in three aspects, namely, the two generations' different attitudes towards new things, personal relationship, and their lifestyles. My peer, however, said that the three aspects were very broad and advised me to narrow them down. Then I chose to focus on the first aspect, the two generations' differing attitudes towards new things, in my revised draft and to have a sufficient treatment of that aspect only. Moreover, my peer also suggested that I make the beginning paragraph concise, reinforce the inter-sentential connections through the use of connectives, and make the concluding paragraph more forceful. Her advice on content and organization revision is really useful (Susan, Interview 3).

In the fifth retrospective interview conducted with her, Susan also talked a little about the effectiveness of peer feedback for revising the language use of her EFL writing. For instance,

As for the effectiveness of peer feedback for improving the language use of my EFL writing, I did not hold very positive opinions. Partly this might be because we are of almost the same age and have very similar levels of English proficiency, and I could not expect her to help me significantly improve the use of vocabulary and sentence structures, especially the appropriateness of language use. Partly this might be because I would generally avoid making grammar and vocabulary mistakes when writing my first draft, and thus there is no need for my peer to point out those mistakes in my drafts (Susan, Interview 5).

Three findings can be derived from the examples above: 1) Susan's peer mostly focused on the global aspects of her EFL writing, which might be because Susan's relatively good command of English enabled her to avoid those obviously observable problems with language use at the drafting stage; 2) Susan was mostly positive about her peer's feedback on the content and organization revisions of her EFL writing; 3) Susan held less positive perceptions of her partner's ability to advise on improving the appropriateness of language use.

\subsection{Intermediate and Low Proficiency Students Forming a Pair: Focus on Local Aspects of EFL Writing}

This subsection presents the pattern of peer-mediated draft revisions of Kelvin, a student of intermediate English proficiency. Kelvin was paired with Nick, a student of low English proficiency. Table 4 lists the number and proportion of Kelvin's peer-mediated draft revisions.

Table 4. Kelvin's draft revisions made in response to peer feedback

\begin{tabular}{lllllll}
\hline Essay & $\begin{array}{l}\text { Content } \\
\text { revisions }\end{array}$ & $\begin{array}{l}\text { Organization } \\
\text { revisions }\end{array}$ & $\begin{array}{l}\text { Vocabulary } \\
\text { revision }\end{array}$ & $\begin{array}{l}\text { Grammar } \\
\text { revisions }\end{array}$ & $\begin{array}{l}\text { Mechanics } \\
\text { revisions }\end{array}$ & Total \\
\hline $1^{\text {st }}$ & $0(0 \%)$ & $0(0 \%)$ & $1(25 \%)$ & $3(75 \%)$ & $0(0 \%)$ & $4(100 \%)$ \\
$2^{\text {nd }}$ & $0(0 \%)$ & $0(0 \%)$ & $3(27 \%)$ & $3(27 \%)$ & $5(46 \%)$ & $11(100 \%)$ \\
$3^{\text {rd }}$ & $0(0 \%)$ & $0(0 \%)$ & $0(0 \%)$ & $1(50 \%)$ & $1(50 \%)$ & $2(100 \%)$ \\
$4^{\text {th }}$ & $1(25 \%)$ & $2(50 \%)$ & $1(25 \%)$ & $0(0 \%)$ & $0(0 \%)$ & $4(100 \%)$ \\
$5^{\text {th }}$ & $0(0 \%)$ & $0(0 \%)$ & $3(60 \%)$ & $2(40 \%)$ & $0(0 \%)$ & $5(100 \%)$ \\
Total & $1(4 \%)$ & $2(8 \%)$ & $8(30 \%)$ & $9(35 \%)$ & $6(23 \%)$ & $26(100 \%)$ \\
\hline
\end{tabular}

The table shows that Kelvin's peer-mediated revisions are mostly about vocabulary $(8,30 \%)$, grammar $(9,35 \%)$, and mechanics $(6,23 \%)$, with relatively few content $(1,4 \%)$ and organization $(2,8 \%)$ revisions made. Compared with Catherine and Susan's peer-mediated draft revisions, Kelvin's peer-mediated mechanics revisions account for a larger percentage $(6,23 \%)$ of his peer-mediated revisions. 
When being interviewed about the peer's role in draft revision, Kelvin straightforwardly expressed his dissatisfaction with Nick's incompetence for giving feedback on his EFL writing. For example,

Well, for the effects of peer assessment, you know, taking the "Great" proficiency level of my peer into consideration, the peer feedback would sometimes be focused on the organization of a composition, but in most cases it would be like 'Ah, you do not put the nouns into plurals here' or 'you have misused the tense there.' He would only pick out such minor problems or mistakes with my language use, without focusing on the appropriate use of vocabulary, let alone the content of my composition. Sometimes he would even fail to recognize the complex sentence structures I used in my writing or confuse the meanings of such words as "occidental" and "accidental", or "gradually" and "generally". How come he would take a long time to recognize an inverted sentence structure or my purposeful use of a subjunctive mood! Taken as a whole, my peer's role in draft revision can be almost ignored (Kelvin, Interview 5).

A sardonic tone can be detected in Kelvin's perceptions of his peer's feedback. Kelvin held mostly negative opinions about his peer's feedback and mainly attributed the lack of efficacy of peer feedback to Nick's low English proficiency.

Three findings can be drawn from Kelvin's pattern of peer-mediated revisions: 1) Although Kelvin expected to receive useful feedback from his peer on both global and local aspects of EFL writing, he mistrusted his peer's competence for providing feedback and tended to depend less on his peer for essay improvement; 2) The low English proficiency of Kelvin's peer, Nick, confined the foci of peer feedback to mainly local aspects of EFL writing; 3) The low English proficiency of Nick also debilitated the effectiveness of peer feedback for improving the local aspects of EFL writing.

\section{Discussion}

The research revealed that different ways of forming students into pairs according to their proficiency levels would result in the variation of peer feedback effects on their draft revisions. For pairs formed by students of high proficiency, the foci in peer assessment were mostly on the global aspects of EFL writing. For pairs formed by students of intermediate proficiency, the foci in peer feedback were almost evenly distributed among all the five aspects of EFL writing. For pairs formed by students of intermediate and low proficiency levels, the peer feedback given by the student of low proficiency was mainly oriented towards the local aspects of EFL writing.

It was also found that when students of similar proficiency levels were paired together, the H-H and I-I dyads in the present study, they held mostly positive perceptions of the peer feedback received. However, when students of intermediate and low proficiency levels formed a pair, the I-L dyad in this research, the student of intermediate proficiency level held mostly negative perceptions of the feedback from his low-proficiency partner. In this sense, the results have more or less verified Strijbos' et al. viewpoint that "feedback from a person with a high level of expertise is assumed to be perceived as more positive than from a person with low expertise" (2010, p. 293) and supported Birnbaum and Stegner's (1979) stance that expertise of peer feedback giving may be affected by peer assessors' competence level.

A hypothetical model (see Figure 1.) on the variation of peer-mediated revisions among pairs is proposed based on the results above. In this model, peer assessors' English proficiency levels and peer assessees' first drafts are two key factors affecting peer assessors' foci on assessees' EFL writing, which would in turn result in the variation of peer-mediated revisions of assessees' drafts.

It is worth noting that this hypothetical model is not intended to account for all the possible variation of peer-mediated revisions among peers paired in similar or different ways. It is only hoped that such a model would shed light on the working mechanisms of peer assessment of EFL writing from the perspective of proficiency-pairing.

The results also showed that the number of revisions students made in response to peer feedback are relatively few. This may be explained by the organization of both rubric-referenced self- and peer feedback sessions in the Chinese EFL writing class. As noted by Strijbos et al. (2010, p. 300), "our feed forward (by providing criteria to all groups at the start of the treatment phase) may have led our participants to self-assess the text and that the external feedback was redundant."

A salient finding is that the dyads formed by two students of intermediate proficiency might have benefited most from peer assessment process, since the peer feedback from an intermediate-proficiency student would generally touch upon all aspects of EFL writing. This may partially support Black and Wiliam's (1998) stance that students of intermediate achievement level seemed to benefit more from formative assessment than students of other achievement levels. 


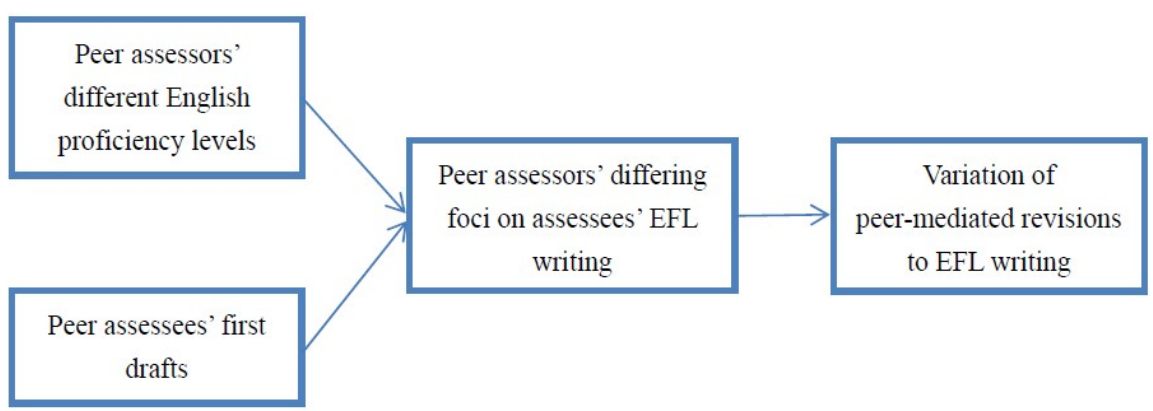

Figure 1. A hypothetical model of the variation of peer-mediated revisions

Despite the attention paid to the influence of different patterns of peer-interaction on students' second language writing development in recent years (e.g., Storch, 2007a, 2007b; Storch \& Aldosari, 2013), the present study contributes to the previous findings on peer-interaction in second language writing research by demonstrating the importance of proficiency-pairing to the success of peer feedback sessions in the Chinese EFL writing context. It showed that it was difficult for a student of intermediate English proficiency to receive effective feedback from a peer of low proficiency. In other words, the low-proficiency student's ability to generate effective feedback was largely constrained by his/her limited English proficiency. For pairs formed by two students of intermediate English proficiency, an intermediate-proficiency student tended to generate peer feedback on all aspects of EFL writing, which might be because of the existence of problems with both global and local aspects of the partner's EFL writing. For dyads formed by students of higher English proficiency, the students tended to generate peer feedback on mainly global aspects of EFL writing, which might be due to the fact that there were less easily identifiable "rule-based" problems in her high-proficiency partner's EFL writing. The findings of the present study have pedagogic implications for forming students into dyads or groups in the Chinese EFL writing context.

\section{Conclusion}

The present study found that proficiency-pairing had a relatively significant impact on students' peer-mediated draft revisions. It demonstrated that despite the same training received by the students in the EFL writing class, the formation of students of different or similar proficiency levels into pairs would lead to the distinct patterns of peer-mediated revisions or peer-interactive learning benefits in terms of EFL writing. Such a classroom-based inquiry has pedagogic implications for organizing peer feedback sessions in the Chinese EFL writing class. Firstly, the study illustrated that training students to give feedback on each other's writing had limited effects on the quality and usage of feedback provided by students of low proficiency. Secondly, it showed that students' attitudes towards peer feedback were inextricably intertwined with their peers' ability to provide feedback on EFL writing. This is particularly obvious when an intermediate-proficiency student was paired with a low-proficiency partner. The intermediate-proficiency student was dissatisfied with the efficacy of his peer's feedback for improving both the global and local aspects of his EFL writing, and his dissatisfaction might in turn negatively affect his reception and usage of the peer's feedback and even diminish the quality of peer feedback sessions. Thirdly, the study demonstrated that pairing intermediate and high-proficiency students into dyads might be a viable way of grouping students into pairs, since both intermediate and high-proficiency students held mostly positive perspectives on the peer feedback received.

Although peer dyads have been proposed as acommon form of organizing students in peer feedback sessions (e.g., Min, 2006; Paulus, 1999), the composition of peer dyads according to students' English proficiency shall be a key consideration in evaluating the effectiveness of peer feedback. To mitigate the negative effects of pairing intermediate and low proficiency students together, the use of multiple-peer groupings comprising three or four students of differing proficiency, ranging from high to low levels, should be considered an alternative to peer dyads. Moreover, the study has also demonstrated the irreplaceable role of teacher feedback in the Chinese EFL writing context. When teachers make comments on their students' EFL writing, student samples of different levels should be used to illustrate necessary improvements that should be made to both global and local aspects of EFL writing. In a Chinese EFL writing context as described in the present study, the teacher should spend more time offering feedback on students' accuracy and appropriateness of language use and pay particular attention to the low-proficiency students' EFL writing, since they may lack the competence for giving useful feedback on either their peers' or possibly their own EFL writing.

The study is a small-scale exploratory study which only investigates three case students' peer-mediated revisions. 
The results, therefore, may not be generalized to other, even similar, contexts. Moreover, because of its exploratory nature, the study has not used a quasi-experimental design and does not establish a strictly causal relationship between proficiency-pairing and students' peer-mediated revisions. Therefore, future studies using a more rigorous research design are needed to investigate a larger sample of students in different L2 writing contexts. Lastly, the present study has only proficiency-pairing as its focus and has not examined how proficiency-pairing and the dyadic relationship between students in peer feedback sessions may interact to bring about students'peer-mediated draft revisions.

\section{References}

Berg, E. C. (1999a). The effects of trained peer response on ESL students' revision types and writing quality. Journal of Second Language Writing, 8(3), 215-241. http://dx.doi.org/10.1016/S1060-3743(99)80115-5

Berg, E. C. (1999b). Preparing ESL students for peer response. TESOL Journal, 8(2), 20-25. http://dx.doi.org/10.1002/j.1949-3533.1999.tb00171.x

Birnbaum, M. H., \& Stegner, S. E. (1979). Source credibility in social judgments: Bias, expertise, and the judges's point of view. Journal of Personality and Social Psychology, 37, 48-74. http://dx.doi.org/10.1037/0022-3514.37.1.48

Black, P., \& Wiliam, D. (1998). Assessment and classroom learning. Assessment in Education: Principles, Policy \& Practice, 5(1), 7-74. http://dx.doi.org/10.1080/0969595980050102

Bruffee, K. A. (1973). Collaborative learning: Some practical models. College English, 34(5), 634-643. http://dx.doi.org/10.2307/375331

Chaudron, C. (1984). The effects of feedback on students' composition revisions. RELC Journal, 15(2), 1-14.

Connor, U., \& Asenavage, K. (1994). Peer response groups in ESL writing classes: How much impact on revision? Journal of Second Language Writing, 3(3), 257-276. http://dx.doi.org/10.1016/1060-3743(94)90019-1

Crookes, G., Davis, K. A., \& Caulk, N. (1994). Comparing teacher and student responses to written work. TESOL Quarterly, 28(1), 181-188. http://dx.doi.org/10.2307/3587209

Guerrero, M. C. M. D., \& Villamil, O. S. (1994). Social-cognitive dimensions of interaction in L2 peer revision. The Modern Language Journal, 78(4), 484-496. http://dx.doi.org/10.2307/328586

Hu, G. (2005). Using peer review with Chinese ESL student writers. Language Teaching Research, 9(3), 321-342.

Jacobs, G., \& Zhang, S. (1989). Peer feedback in second language writing instruction: Boon or bane? Paper presented at the The Annual Meeting of the American Educational Research Association, San Francisco, CA, March 27-31.

Jacobs, H., Zinkgraf, S., Wormuth, D., Hartfiel, V., \& Hughey, J. (1981). Testing ESL composition: A practical approach. Rowley, MA: Newbury House.

Leeser, M. J. (2004). Learner proficiency and focus on form during collaborative dialogue. Language Teaching Research, 8(1), 55-81.

Liou, H., \& Peng, Z. (2009). Training effects on computer-mediated peer review. System, 37(3), 514-525. http://dx.doi.org/10.1016/j.system.2009.01.005

Lockhart, C., \& Ng, P. (1995). Analyzing talk in ESL peer response groups: Stances, functions, and content. Language Learning, 45(4), 605-651. http://dx.doi.org/10.1111/j.1467-1770.1995.tb00456.x

Mei, T., \& Yuan, Q. (2010). A case study of peer feedback in a Chinese EFL writing classroom. Chinese Journal of Applied Linguistics, 4, 87-98.

Mendonca, C. O., \& Johnson, K. E. (1994). Peer review negotiations: Revision activities in ESL writing instruction. TESOL Quarterly, 28(4), 745-769. http://dx.doi.org/10.2307/3587558

Merriam, S. B. (1998). Qualitative research and case study applications in education: Revised and expanded from case study research in education. San Francisco: Jossey-Bass Publishers.

Min, H. (2005). Training students to become successful peer reviewers. System, 33(2), 293-308. http://dx.doi.org/10.1016/j.system.2004.11.003

Min, H. (2006). The effects of trained peer review on EFL students' revision types and writing quality. Journal 
of Second Language Writing, 15(2), 118-141. http://dx.doi.org/10.1016/j.jslw.2006.01.003

Min, H. (2008). Reviewer stances and writer perceptions in EFL peer review training. English for Specific Purposes, 27(3), 285-305. http://dx.doi.org/10.1016/j.esp.2008.02.002

Nelson, G. L., \& Murphy, J. M. (1993). Peer response groups: Do L2 writers use peer comments in revising their drafts? TESOL Quarterly, 27(1), 135-141. http://dx.doi.org/10.2307/3586965

Paulus, T. M. (1999). The effect of peer and teacher feedback on student writing. Journal of Second Language Writing, 8(3), 265-289. http://dx.doi.org/10.1016/S1060-3743(99)80117-9

Rahimi, M. (2013). Is training student reviewers worth its while? A study of how training influences the quality of students' feedback and writing. Language Teaching Research, 17(1), 67-89.

Rollinson, P. (2005). Using peer feedback in the ESL writing class. ELT Journal, 59(1), 23-30.

Sengupta, S. (1998). Peer evaluation: 'I am not the teacher'. ELT Journal, 52(1), 19-28.

Shih-hsien, Y. (2011). Exploring the effectiveness of using peer evaluation and teacher feedback in college students' writing. The Asia-Pacific Education Researcher, 20(1), 144-150.

Stanley, J. (1992). Coaching student writers to be effective peer evaluators. Journal of Second Language Writing, 1(3), 217-233. http://dx.doi.org/10.1016/1060-3743(92)90004-9

Storch, N. (1998). A classroom-based study: Insights from a collaborative text reconstruction task. ELT Journal, 52(4), 291-300.

Storch, N. (2002a). Patterns of Interaction in ESL Pair Work. Language Learning, 52(1), 119-158. http://dx.doi.org/10.1111/1467-9922.00179

Storch, N. (2002b). Relationships formed in dyadic interaction and opportunity for learning. International Journal of Educational Research, 37(3-4), 305-322. http://dx.doi.org/10.1016/S0883-0355(03)00007-7

Storch, N. (2005). Collaborative writing: Product, process, and students' reflections. Journal of Second Language Writing, 14(3), 153-173. http://dx.doi.org/10.1016/j.jslw.2005.05.002

Storch, N. (2007a). How collaborative is pair work? ESL tertiary students composing in pairs. Language Teaching Research, 11(2), 189-207.

Storch, N. (2007b). Investigating the merits of pair work on a text editing task in ESL classes. Language Teaching Research, 11(2), 143-159.

Storch, N., \& Aldosari, A. (2013). Pairing learners in pair work activity. Language Teaching Research, 17(1), 31-48.

Strauss, A., \& Corbin, J. (1998). Basics of qualitative research: Techniques and procedures for developing grounded theory. Thousand Oaks: Sage.

Strijbos, J., Narciss, S., \& Dnebier, K. (2010). Peer feedback content and sender's competence level in academic writing revision tasks: Are they critical for feedback perceptions and efficiency? Learning and Instruction, 20(4), 291-303. http://dx.doi.org/10.1016/j.learninstruc.2009.08.008

Strijbos, J., \& Sluijsmans, D. (2010). Unravelling peer assessment: Methodological, functional, and conceptual developments. Learning and Instruction, 20(4), 339-343. http://dx.doi.org/10.1016/j.learninstruc. 2009.08.002

Topping, K. J. (1998). Peer assessment between students in colleges and universities. Review of Educational Research, 68(3), 249-276.

Topping, K. J. (2010). Peers as a source of formative assessment. In H. L. Andrade, \& G. J. Cizek (Eds.), Handbook of Formative Assessment (pp. 61-74). New York: Routledge.

Tsui, A. B. M., \& Ng, M. (2000). Do secondary L2 writers benefit from peer comments? Journal of Second Language Writing, 9(2), 147-170. http://dx.doi.org/10.1016/S1060-3743(00)00022-9

Villamil, O. S., \& de Guerrero, M. C. M. (1996). Peer revision in the L2 classroom: Social-cognitive activities, mediating strategies, and aspects of social behavior. Journal of Second Language Writing, 5(1), 51-75. http://dx.doi.org/10.1016/S1060-3743(96)90015-6

Villamil, O. S., \& Guerrero, M. C. M. D. (1998). Assessing the Impact of Peer Revision on L2 Writing. Applied Linguistics, 19(4), 491-514. 
Vygotsky, L. S. (1978). Mind in society: The development of higher psychological processes. Cambridge, MA: Harvard University Press.

Watanabe, Y. (2008). Peer-Peer Interaction between L2 Learners of Different Proficiency Levels: Their Interactions and Reflections. Canadian Modern Language Review, 64(4), 605-635. http://dx.doi.org/10.3138/cmlr.64.4.605

Watanabe, Y., \& Swain, M. (2007). Effects of proficiency differences and patterns of pair interaction on second language learning: Collaborative dialogue between adult ESL learners. Language Teaching Research, 11(2), 121-142.

Yang, M., Badger, R., \& Yu, Z. (2006). A comparative study of peer and teacher feedback in a Chinese EFL writing class. Journal of Second Language Writing, 8(3), 265-289. http://dx.doi.org/10.1016/ j.jslw.2006.09.004

Zhang, S. (1995). Reexamining the affective advantage of peer feedback in the ESL writing class. Journal of Second Language Writing, 4(3), 209-222. http://dx.doi.org/10.1016/1060-3743(95)90010-1

Zhao, H. (2010). Investigating learners' use and understanding of peer and teacher feedback on writing: A comparative study in a Chinese English writing classroom. Assessing Writing, 15(1), 3-17. http://dx.doi.org/10.1016/j.asw.2010.01.002

Zhu, W. (1995). Effects of training for peer response on students' comments and interaction. Written Communication, 12(4), 492-528.

Zhu, W. (2001). Interaction and feedback in mixed peer response groups. Journal of Second Language Writing, 10(4), 251-276. http://dx.doi.org/10.1016/S1060-3743(01)00043-1

\section{Appendix A}

Assigned essay topics

\begin{tabular}{lll}
\hline Time & Essay Topics & Writing Techniques Required \\
\hline Week 4, Semester 1 & College Pressures & Illustration \\
Week 9, Semester 1 & Why Don’t We Complain & Cause and Effect \\
Week 14, Semester 1 & The Post-90 Generation and Others & Comparison and Contrast \\
Week 10, Semester 2 & On Growth & Definition \& Illustration \\
Week 15, Semester 2 & The Best Way to Understand the World & Definition, Illustration \& Cause \& Effect \\
\hline
\end{tabular}

\section{Appendix B}

Interview questions on students' perceptions and usage of peer-feedback

1) Please spend fifteen minutes reading the first and second drafts of your expository writing. Pay attention to the marks that show the changes you have made to the first draft. Note those parts that you have revised in response to peer-feedback and reflect on the process of peer-feedback usage.

2) What are your general feelings about the peer-feedback on your EFL writing?

3) Please specify the peer-mediated draft revisions and explain your decision-making process when revising your drafts in response to peer-feedback.

4) What aspects of EFL writing do you think peer feedback is effective for revising? Why?

5) What aspects of EFL writing do you think peer feedback is not so effective for revising? Why?

6) How do you evaluate your peer's competence for giving peer feedback on your EFL writing? (Asked when the students' were interviewed for the last time)

\section{Copyrights}

Copyright for this article is retained by the author(s), with first publication rights granted to the journal.

This is an open-access article distributed under the terms and conditions of the Creative Commons Attribution license (http://creativecommons.org/licenses/by/3.0/). 